\section{The earthworm Dendrobaena veneta (Annelida): A new experimental-organism for photobiomodulation and wound healing}

\author{
Andrea Amaroli, ${ }^{1,2}$ Sara Ferrando, ${ }^{2}$ \\ Marina Pozzolini, ${ }^{3}$ Lorenzo Gallus, ${ }^{2}$ \\ Steven Parker, ${ }^{1}$ Stefano Benedicenti ${ }^{1}$ \\ ${ }^{1}$ Department of Surgical Sciences and \\ Integrated Diagnostic, University of \\ Genoa \\ ${ }^{2}$ Department of Earth, Environmental \\ and Life Sciences, Laboratory of New \\ Model Organism (NeMoLAB), \\ University of Genoa \\ ${ }^{3}$ Department of Earth, Environmental \\ and Life Sciences, Laboratory of Marine \\ Biotechnology, University of Genoa, \\ Italy
}

\begin{abstract}
Photobiomodulation (PBM) is a manipulation of cellular behavior using non-ablative low intensity light sources. This manipulation triggers a cascade of metabolic effects and physiological changes resulting in improved tissue repair, of benefit in the treatment of tissue injury, degenerative or autoimmune diseases. PBM has witnessed an exponential increase in both clinical instrument technology and applications. It is therefore of benefit to find reliable experimental models to test the burgeoning laser technology for medical applications. In our work, we proposed the earthworm Dendrobaena veneta for the study of nonablative laser-light effects on wound healing. In our preliminary work, $D$. veneta has been shown to be positively affected by PBM. New tests using $D$. veneta were set up to evaluate the effectiveness of a chosen $808 \mathrm{~nm}-64 \mathrm{~J} / \mathrm{cm}^{2}-1 \mathrm{~W}-\mathrm{CW}$ laser therapy using the AB2799 hand-piece with flat-top bean profile, on the wound healing process of the earthworm. Effective outcome was assimilated through examining the macroscopic, histological, and molecular changes on the irradiated posterior-segment of excised-earthworms with respect to controls. Three successive treatments, one every 24 hours, were concluded as sufficient to promote the wound healing, by effects on muscular and blood vessel contraction, decrement of bacteria load, reduction of inflammatory processes and tissue degeneration. D. veneta was demonstrated to be a reliable experimental organism that meets well the 3 Rs principles and the
\end{abstract}

National Science Foundation statement. Through their genetic and evolutionary peculiarity, comparable to those of scientifically accredited models, $D$. veneta allows the effect of laser therapies by multidisciplinary methods, at various degree of complexity and costs to be investigated.

\section{Introduction}

A few years after the first working laser was invented, Endre Mester and coworkers, ${ }^{1}$ while applying low-level laser energy irradiation to the backs of shaved mice, noticed that the shaved hair grew back more quickly on the treated group than the untreated group. This manipulation of cellular behavior using low intensity light sources (non-ablative) was referred to as photobiomodulation (PBM). Conceptually, $\mathrm{PBM}$ and the application of photonic energy of specific individual wavelengths works on the principle of inducing a biological response through energy delivery and transfer into the tissue, modulating biological processes within that tissue and within the biological system of which that tissue is a part. ${ }^{2}$ Photonic energy incorporated within a molecular structure, may increase kinetic energy, activate or deactivate enzymes or alter physical or chemical properties of main macromolecules. Growth factor response within cells and tissue as a result of increased cellular energy and protein synthesis, together with a change in cell membrane permeability to $\mathrm{Ca}^{2+}$ uptake, may lead to cell proliferation. ${ }^{3-5}$ This may form part of a cascade of metabolic effects and physiological changes resulting in improved tissue repair associated with injuries, degenerative diseases or autoimmune diseases. ${ }^{6}$ However, a lot of confusion still reigns in this field since to date, the correct laser parameters and resultant applied energy density that effectively promote cell rescue without significant side effects, are still elusive. Limited evidence suggests that the energy can be applied with the same efficiency from cellular to organismic level. ${ }^{7}$ Indeed, if the photonic energy can have a photobiomodulatory positive effect on in vitro cells and tissues, that energy must reach target cell at the appropriate intensity to be effective in vivo. It is possible that this may be due to incomplete knowledge surrounding the biochemical mechanisms underlying the PBM positive effect. Additionally, there is the complex influence of choice among a large number of operating parameters such as wavelength of the applied electromagnetic energy, the absorbing chromophores within the target tissue, the energy density or fluence of the applied electromagnetic energy and the
Correspondence: Prof. Stefano Benedicenti, Department of Surgical Sciences and Integrated Diagnostic, University of Genoa, Largo R. Benzi 10, 16132 Genova, Italy.

E-mail: stefano.benedicenti@unige.it

Key words: Low Level Laser Therapy; laser irradiation; scarring; anti-inflammatory; tissue repair; Heat Shock Protein; cell proliferation.

Contributions: AA, SF, SB, experiments concept and design; AA, LG, MP, SF, experiments performing, data collection, data analyses; SB, SP, analysis tools providing; AA, MP, SB, SF, $\mathrm{SP}$, manuscript drafting.

Conflict of interest: The authors state no conflict of interest and have received no payment in preparation of this manuscript.

Acknowledgements: We are grateful to Dr. Marino Rottigni and Dr. Giulia Damiano for invaluable experimental support.

Received for publication: 3 November 2017. Accepted for publication: 15 January 2018.

This work is licensed under a Creative Commons Attribution-NonCommercial 4.0 International License (CC BY-NC 4.0).

(C) Copyright A. Amaroli et al., 2018

Licensee PAGEPress, Italy

European Journal of Histochemistry 2018; 62:2867 doi:10.4081/ejh.2018.2867

power density or irradiance of the applied electromagnetic energy. ${ }^{4,8}$ In addition, the application of PBM using "standard" (hitherto conventional) hand-piece is determined by its very features. Through beam divergence, the applied energy is distributed over an increasing area as the tip-to-tissue distance increases, dramatically affecting energy density at cellular level. ${ }^{8}$ Laser energy emitted from a standard hand-piece is not evenly distributed across its emitting surface. In almost all instances it has a Gaussian profile, so the density of the photons is significantly higher at the center of the beam and lower at its outskirts. ${ }^{8,9}$ In order to overcome these problems, PBM has witnessed an exponential increase in both clinical instrument technology and applications. It is therefore of benefit to find reliable experimental models to test the burgeoning laser technology for medical applications. Recently, a novel hand-piece (AB2799) with flat-top bean profile has been produced (LAMBDA SpA, Vicenza, Italy). This particular probe provides homogeneous irradiation and energy density, its beam is non-divergent and provides the same power density over any tip-to-tissue distance from contact to $100 \mathrm{~cm}$ (see product characteristics on http://www.lambdaspa.com/en/). In our previous papers, ${ }^{10,11}$ we 
proposed the unicellular eukaryotic organism Paramecium primaurelia as a model to test novel PBM therapies and laser technologies. Through these investigations with $P$. primaurelia, we showed that the higherfluence $\left(64 \mathrm{~J} / \mathrm{cm}^{2}\right)$ using higher-power (1 $\mathrm{W})$, continuous wave (CW) irradiation, with the AB2799, is able to induce PBM, affecting mitochondrial activity, ${ }^{9}$ increasing oxygen consumption, ${ }^{10}$ and ATP production, ${ }^{12,13}$ as well as modulating $\mathrm{Ca}^{2+}$ fluxes, $\mathrm{Ca}^{2+}$ stored release, nitric oxide production and cilia beating. ${ }^{12-14}$ In addition, the higher-fluence higher-power irradiation by flat-top hand-piece of gametes and embryos of the sea urchin Paracentrotus lividus, does not affect the DNA and does not generate aberration. ${ }^{15}$ In the current work, we moved from the unicellular to the multicellular level and we propose an animal experimental organism to test the photobiomodulatory effect of PBM on wound healing. An attempt to find more ethical and more human closed model organism, which meets well the 3Rs (Replacement, Reduction, Refinement) principles, ${ }^{16}$ has emerged through recent decades. The words "model organism", "model species" or "model animal" are more and more used in different science fields. Some of these models have consequentially been promoted for "human health", while others have been ignored but without real motivation. ${ }^{17,18}$ The accredited models for the study of inflammatory process, wound healing and regeneration are both Vertebrates (Mus musculus, Rattus norvegicus, Danio rerio, Xenopus laevis) $)^{19,20}$ and Invertebrates (Caenorhabditis elegans, Drosophila melanogaster). ${ }^{19}$ However, the responses to inflammatory stress in the mouse model are not so easily correlated to that of humans. ${ }^{21}$ In addition, as reviewed by Katz ${ }^{18}$ "Thomas Hunt Morgan, the father of Drosophila genetics, never once referred to Drosophila as a model organism in his iconic books. He cited the advantages of choosing the fly Drosophila as an experimental organism, but he never used the word "model". After all, he was not studying a model of the mechanisms of heredity; he was studying the actual mechanism of heredity. Sydney Brenner did not refer to the worm Caenorhabditis elegans as a model organism in his classic work on its genetics". Basically, in a scientific-world where the future of medicine is the "Personalized Medicine", 22 the concept of "model for human health" is actually being questioned. ${ }^{18}$ Therefore, according to Katz ${ }^{18}$ in our work we proposed Dendrobaena veneta as an "experimental organism" for the study of non-ablative laser light effects on the wound healing.

Earthworms, as annelids, are segmented worms and belong to the group of Clitellata.
When mature, they have a visible set of swollen segments, the clitellum, specialized for reproduction. The anterior part of the body, from the mouth to the clitellum (in $D$. veneta roughly 30 segments), contains several different organs (e.g., ovaries, testes, multicellular glands, cerebral ganglia, nephridia, specialized regions of the alimentary canal such as pharynx, crop, and gizzard). Posteriorly to the clitellum, there are several tenths of segments that are anatomically more homogeneous, excluding the few, very caudal ones. ${ }^{23}$ In our preliminary work, ${ }^{24} \mathrm{D}$. veneta showed to be promising model, which was positively affected by PBM. In the present work, we focalized our attention to the wound healing in the posterior part of $D$. veneta, where all the segments share the following anatomy. The body wall is a muscular structure covered externally by a cuticle and epidermis and internally by the peritoneum. ${ }^{25}$ The anatomical structures in the coelomic cavity, running along the body length, are the gut, enveloped in a chloragogen layer, the major dorsal and ventral blood vessels, and the ventral nerve cord. Furthermore, a couple of nephridia are present laterally in each segment. ${ }^{23}$. In the fluid that fills the coelomic cavity are present free coelomocytes; they are a heterogeneous population of cells. The main cell types are amebocytes, deriving from the peritoneum, and eleocytes, deriving from the chloragogen layer. ${ }^{26}$ The body-wall muscle is formed by two layers of helical muscle fibers; they are elongated mononucleated cells, with spirally-arranged sarcomeres and well developed, tubular, sarcoplasmic reticulum. ${ }^{27,28}$ When the body of the earthworm is transversally sectioned both the gut eversion and the formation of a coelomocytes-formed coelomic plug can be involved in wound closure. ${ }^{25}$. To reach our goal, we set up new tests on $D$. veneta to evaluate the effectiveness of the $808 \mathrm{~nm}-64 \mathrm{~J} / \mathrm{cm}^{2}-1 \mathrm{~W}$ laser therapy irradiated with the AB2799 hand-piece, on the wound healing process of that earthworm, by examining the macroscopic, histological, and molecular changes on the irradiated posterior-segment of excised-earthworms with respect to controls.

\section{Materials and Methods}

\section{Dendrobaena veneta (Phylum: Annelida, Class: Oligochaeta)}

D. veneta (also sometimes called Eisenia hortensis) is a hermaphrodite robust earthworm that grows very rapidly and may tolerate much wider moisture ranges than many other species; it prefers temperature in the range of $15-25^{\circ} \mathrm{C} .{ }^{29}$ Its life cycle can be completed in 100-150 days and 65 days is the average time to reach sexual maturity. ${ }^{29}$

$D$. veneta can be easily bred in laboratory, in standard conditions, without addition of animal manure, by organic soil and vegetable or oatmeal as food. ${ }^{24-29}$

\section{Experimental setting}

$D$. veneta were obtained from Redbug S.r.l. (Milan, Italy), acclimated in laboratory into organic soil at a temperature of $22 \pm 1^{\circ} \mathrm{C}$ and oatmeal fed. ${ }^{24}$ The experimental setting was performed as summarized in Table 1 . Adult clitelled selected specimens with a similar length ( 150 segments), weight $(\sim 1.5 \mathrm{~g})$ and color were rinsed with water and anesthetized on an ice block for a few minutes. ${ }^{29}$ Under sterile laminar flow hood, 30 posterior segments were excised from the animals and non-irradiated (control) or irradiated with a $808 \mathrm{~nm}$ diode (Doctor Smile, LAMBDA Spa) using a hand-piece with flat-top bean profile (AB2799, Doctor Smile, LAMBDA Spa), with a fluence of 64 $\mathrm{J} / \mathrm{cm}^{2}$ and a power of $1 \mathrm{~W}$ in CW. Laser irradiation was performed with the hand-piece at $1 \mathrm{~mm}$ away from the samples, immediately after the excisions $(0 \mathrm{~h})$ and $24 \mathrm{~h}$ and $48 \mathrm{~h}$ thereafter. The irradiated and non-irradiated excised posterior segments were placed in individual sterile Petri dishes $(\varnothing$ $19 \mathrm{~cm}$ ), with $60 \mathrm{gr}$ of organic soil and 50 $\mathrm{mL}$ of water. The samples were kept under this experimental condition for up to twelve-days and $20 \mathrm{~mL}$ of water was added every three days.

Simple organisms like the worms show a high-ability for wound healing and regeneration. Therefore, in our experiments, to point out the laser treatments' effectiveness, we chose to excise the 30-posterior segments because the literature reported this condition induces the death of the $100 \%$ excised samples, within 15 days, as a consequence of the lack of healing. ${ }^{30}$

The irradiated and non-irradiated samples were analyzed at different time intervals for the evaluation of bacteria load, macroscopic changes, histochemical and immunohistochemical analysis, expression of HSP70 and telomerase activity.

\section{Sample temperature analysis}

The temperature of the excised posterior segments was measured in 5 points of the earthworm section, before and after the irradiation by a Testo 826-T4 infrared thermometer with laser marking (Testo Spa, Milan, Italy).

\section{Bacterial load analysis}

The irradiated and non-irradiated excised posterior segments were immediately swabbed, under sterile laminar flow 
hood, on either Tryptic Soy Agar (15 g/L agar, $15 \mathrm{~g} / \mathrm{L}$ peptone from pancreatic digest casein, $5 \mathrm{~g} / \mathrm{L}$ papaicsoy peptone, $5 \mathrm{~g} / \mathrm{L}$ sodium chloride, $\mathrm{pH} 7.4)$ or in LB broth $(10 \mathrm{~g} / \mathrm{L}$ tryptone, $5 \mathrm{~g}$ yeast extract, $10 \mathrm{~g} / \mathrm{L}$ sodium chloride, $\mathrm{pH}$ 7.4). The Tryptic Soy Agar and the LB broth were kept in the incubator (Gallenkamp $\mathrm{GmbH}, \mathrm{UK}$ ) at $22^{\circ} \mathrm{C}(D$. vene$t a$ 's breeding temperature), for $24 \mathrm{~h}$. After $24 \mathrm{~h}$ the Tryptic Soy Agar was photographed and the images acquired by the Zeiss stereomicroscope with a Cellpad E (TiEsseLab s.r.l., Milan, Italy). The bacteria load was deduced by the measurement with Image J 1.33J software (National Institute of Health, Bethesda, MD, USA) of the bacterized area. In addition, the bacterized areas were carefully collected, suspended in LB broth and the bacteria loads were detected spectrophotometrically by a Jenway-6405UV-Vis Spectrophotometer (Jenway, Felsted, Dunmow Essex, UK). The bacteria load of the experiments in LB broth was deduced spectrophotometrically by a Jenway-6405-UV-Vis Spectrophotometer, at 3, 6 and $24 \mathrm{~h}$ after the swab.

\section{Macroscopic changes analysis}

The irradiated and non-irradiated excised posterior segments were examined by a Zeiss stereomicroscope, immediately after the irradiation or the non-irradiation (t0) and every $24 \mathrm{~h}$ from those. The images were acquired with a Cellpad E (TiEsseLab s.r.1.). The vitality of the segments was evaluated by prodding with a metal tip. The stimulation reactions were observed. No reaction was considered as synonymous with the death of the organism.

\section{Histochemical analysis}

The $24 \mathrm{~h}-, 48 \mathrm{~h}$ - and $72 \mathrm{~h}$-irradiated and non-irradiated excised posterior segments were fixed in $4 \%$ paraformaldehyde in a $0.1 \mathrm{M}$ phosphate buffered solution (PBS, $\mathrm{pH} 7.4$ ) at $4^{\circ} \mathrm{C}$, Paraplast (Bio-Optica Spa, Milan, Italy) embedded and cut into 5- $\mu \mathrm{m}$ thick sections. Histological observations were performed using hematoxylin-eosin (H\&E) and Masson's trichrome. The Alexa 488-conjugated lectin wheat germ agglutinin (WGA; source: Triticum vulgaris, binding specificity: $\mathrm{N}$-acetylglucosamine and $\mathrm{N}$-acetylneuraminic acid, working dilution: $10 \mathrm{mg} / \mathrm{mL} \quad$ - Termofisher Scientific, Waltham, MA, USA) was used. DNA presence was identified, when necessary, by 4',6-diamidino-2-phenylindole

Table 1. Description of the irradiation parameters and experimental design.

\begin{tabular}{|c|c|c|c|c|}
\hline \multicolumn{5}{|c|}{ Irradiation parameters } \\
\hline Laser & Wavelength & Hand-piece & Electromagnetic wave & Power \\
\hline Diode & $808 \mathrm{~nm}$ & Flat-top & Continuous wave & $1 \mathrm{~W}$ \\
\hline Irradiation time & Fluence & Irradiance & Distance & Treatments \\
\hline $60 \mathrm{sec}$ & $64 \mathrm{~J} / \mathrm{cm}^{2}$ & $1 \mathrm{~W} / \mathrm{cm}^{2}$ & $1 \mathrm{~mm}$ & $0 \mathrm{~h}, 24 \mathrm{~h}, 48 \mathrm{~h}$ from excision \\
\hline \multicolumn{5}{|c|}{ Experimental design } \\
\hline Organism & \multicolumn{2}{|c|}{ Segments number } & Weight & Segment excised \\
\hline Dendrobaena veneta & \multicolumn{2}{|c|}{$\sim 150$} & $\sim 1.5 \mathrm{gr}$ & 30 \\
\hline
\end{tabular}
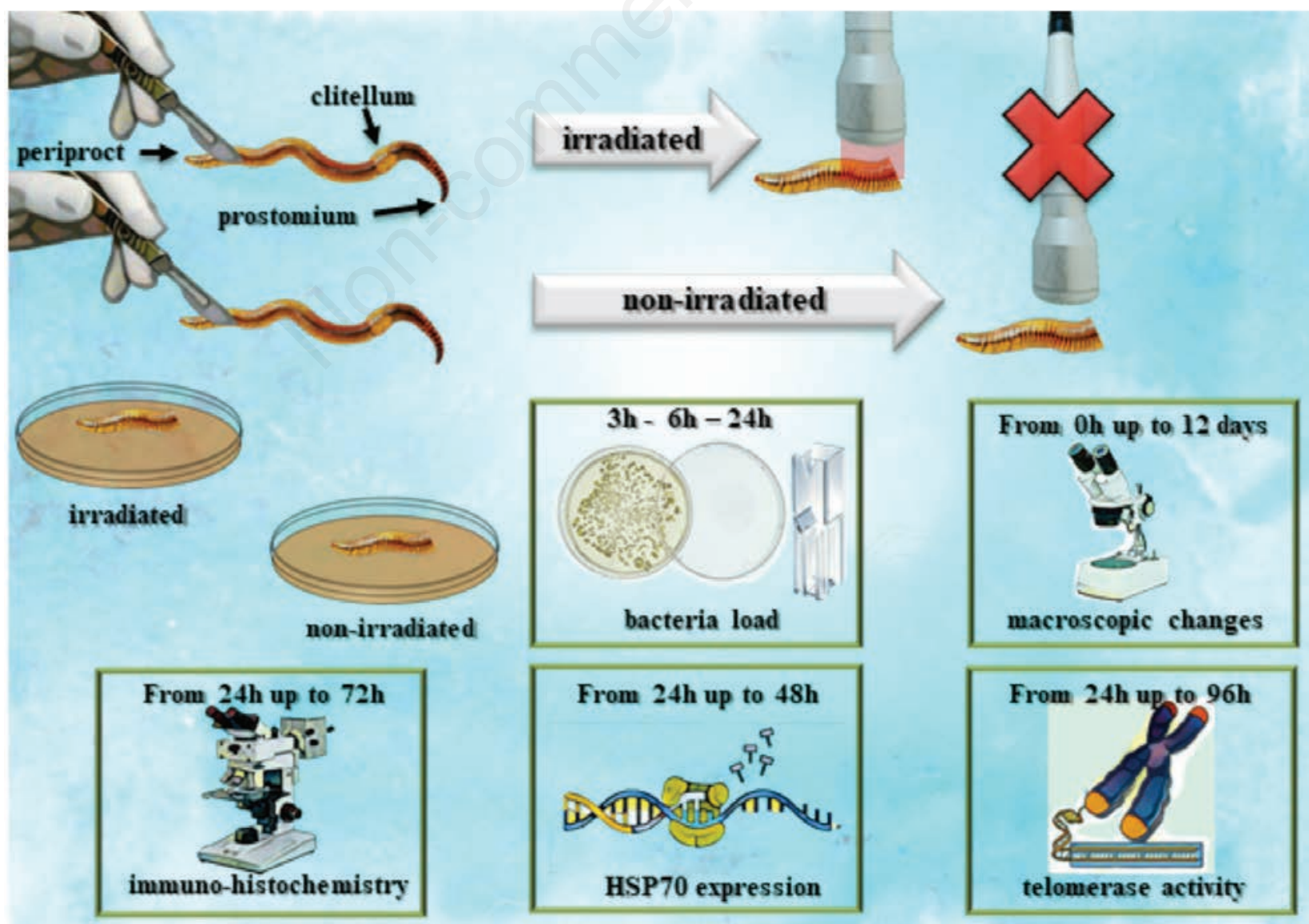
(DAPI) fluorescence staining. Sections were examined on a Leica DMRB light and epifluorescence microscope; images were acquired with a Leica CCD camera DFC420C (Leica, Heerbrugg, Switzerland).

\section{HSP70 expression analysis}

Immune responses to heat shock proteins (HSP) develop in virtually all inflammatory diseases and evidence on antiinflammatory effects of HSP70 are shown in literature. ${ }^{31}$

Therefore, the amount of HSP70 mRNA (MF093577) in excised posterior segments of $24 \mathrm{~h}$ - and $48 \mathrm{~h}$-irradiated and non-irradiated $D$. veneta was determined by qPCRusing Chromo 4 apparatus (MJ Research, Waltham, MA, USA).

First total RNA was extracted from frozen liquid nitrogen tissue samples using RNeasy Mini Kit (QIAGEN, Milan, Italy) and RNase-Free DNase Set (QIAGEN) according to manifacturer's instructions. Then worm cDNA was synthesized by iScript reverse transcriptase (Bio-RAD, Hercules, CA, USA) in a final volume of $20 \mu \mathrm{L}$ using $500 \mathrm{ng}$ of purified total RNA. Subsequently, each PCR reaction was performed in $20 \mu \mathrm{L}$ containing: $1 \times$ master mix iQSYBR ${ }^{\circledR}$ Green (Bio-Rad), $0.2 \mu \mathrm{M}$ of each primer, and $0.8 \mu \mathrm{L}$ of synthesized cDNA or negative control. All samples were analyzed in triplicate. The reference gene used for the samples normalization was D. veneta $18 \mathrm{~S}$ ribosomal RNA gene (KJ911964.1) whose primers sequence were (5'CCGTAACTCTGATGACTCTG) forforward and (5'CTTCCTTGGATGTGGTAGC $3^{\prime}$ ) for reverse while the HSP70 primers sequence were (5' GGACAACAACCTCCTTGGAA 3') for forward (5, CGAAGGTTACCTCGATCTGG 3') for reverse. All primers were designed using the software Beacon Designer 7.0 (PREMIER Biosoft International, Palo Alto, CA, USA) and obtained from TibMolBiol (Genoa, Italy). The following thermal conditions were used: initial denaturation for $3 \mathrm{~min}$, followed by 45 cycles with denaturation at $95^{\circ} \mathrm{C}$ for $15 \mathrm{~s}$, annealing and elongation at $60^{\circ} \mathrm{C}$ for $30 \mathrm{~s}$. The fluorescence was measured at the end of each elongation step. The next step was a slow heating $\left(1^{\circ} \mathrm{C} / \mathrm{s}\right)$ of the amplified product from $55^{\circ} \mathrm{C}$ to $92^{\circ} \mathrm{C}$ in order to generate a melting temperature curve. Data analyses were obtained using the DNA Engine Opticon ${ }^{\circledR} 3$ Real-Time Detection System Software program (ver. 3.03) and, in order to detect the relative gene expression of HSP70, compared with a calibrator sample (uncut worm), the comparative threshold $\mathrm{Ct}$ method $^{32}$ was used with the software GeneExpression Analysis for iCycleriQ Real-Time Detection System (Bio-Rad). ${ }^{33}$

\section{Telomerase activity analysis}

The telomerase activity is typically correlated to cellular proliferation during wound healing. ${ }^{34}$

Therefore, the 24 h-, 48 h-, 72 h- and 96 h-irradiated and non-irradiated excised posterior segments were frozen in liquid nitrogen and their proliferative status was detected by qPCR using the "Quantitative Telomerase Detection kit" (Allied Biotech, Inc., Benicia, CA, USA), following the manufacture's instruction. The amount of extracted protein used in each sample was 1 $\mu \mathrm{g}$. To correlate the $\mathrm{Ct}$ obtained in the different samples, a standard curve was prepared with a 1:5 serial dilution of an oligonucleotide (TSR) supplied by the kit and the enzymatic activity was finally expressed as attomoles per microgram protein. Specifically, values for $24 \mathrm{~h}-, 48 \mathrm{~h}$-, $72 \mathrm{~h}$ - and $96 \mathrm{~h}$-irradiated samples were compared to $24 \mathrm{~h}-, 48 \mathrm{~h}-, 72 \mathrm{~h}-$ and $96 \mathrm{~h}$ non-irradiated samples ones.

\section{Statistical analysis}

The statistical analysis was performed using a one-way ANOVA followed by the
Tukey-Kramer multi-comparison test (GraphPadInStat 3) to discriminate statistically significant results. High significance level: $\mathrm{P}<0.001 \quad(* * *)$, significance level: $\mathrm{P}<0.01(* *)$, significance level: $\mathrm{P}<0.05(*)$, not-significant level: $\mathrm{P}>0.05$. Each experiment was carried out by 3 replications and 5 repetitions.

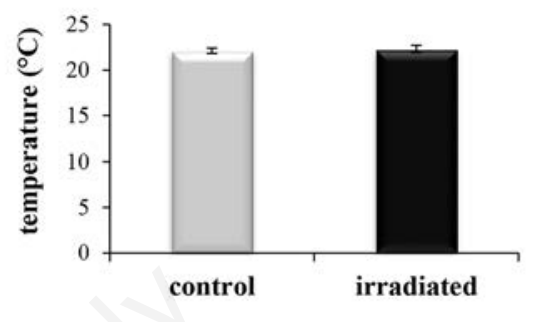

Figure 1. Effect of the laser irradiation on the temperature of Dendrobaena veneta excised side. The temperature was measured before (control) and after (irradiated) the laser irradiation.
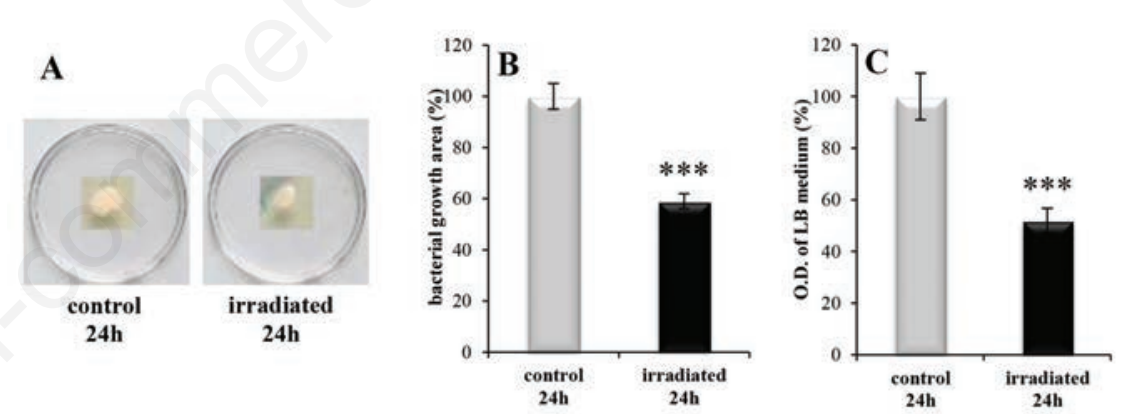


\section{Results}

\section{Evaluation of thermic increment}

The temperature of the excised posterior segments was $22.0^{\circ} \mathrm{C} \pm 0.2$ before the irradiation and $22.5^{\circ} \mathrm{C} \pm 0.4$ afterwards (Figure 1). The difference between the measures did not constitute statistical significance ( $\mathrm{P}>0.05$, data not shown $)$.

\section{Evaluation of bacteria load analysis}

The analysis of the excised posterior segments swabs showed that the bacterized area on the Tryptic Soy Agar was reduced in the irradiated samples $(-41 \%)$ compared to the non-irradiated posterior segments $(\mathrm{P}<0.001)$ (Figure 2A, B). The spectrophotometric analyses of the bacterized area emphasizes these differences, quantifying the bacteria load of the irradiated sample as $52 \%$ less than the non-irradiated sample $(\mathrm{P}<0.001)$ (Figure 2C). In addition, the spectrophotometric analysis of the LB bacterized broth, $3 \mathrm{~h}, 6 \mathrm{~h}$ and $24 \mathrm{~h}$ after the swab, showed that the irradiation reduced the LB bacteria load by about $45 \%, 40 \%$ and $62 \%$, respectively $(\mathrm{P}<0.001)$ (Figure 2D).

\section{Evaluation of survival rate}

The reaction to the external stimulus showed that, 6 days after the excision, $100 \%$ of both irradiated and non-irradiated excised posterior segments were alive $(\mathrm{P}>0.05)$ (Figure 3$)$, with the irradiated excised posterior segments appearing more vital and dynamic. 9 days and 12 days after the excision, $100 \%$ of the irradiated samples were healthy, while only $75 \%$ and $50 \%$ respectively, of the non-irradiated samples appeared vital $(\mathrm{P}<0.001)$ (Figure 3$)$. Finally, 16 days after the excision, all the non-irradiated segments succumbed, whereas $100 \%$ of the irradiated segments survived $(\mathrm{P}<0.001)$ (Figure 3).

\section{Evaluation of macroscopic changes}

Immediately after the 30 posterior segment excision the analysis by stereomicroscopy revealed the evagination of the alimentary tract and the major blood vessel. The coelom cavity was open and the coelomic fluid emerged as well as the blood. The body wall was loose and the wound appearance revealed a circular section of diameter similar to the uncut body diameter (Figure 4 A,B). After the first laser treatment, performed 2 minutes after the excision $(0 \mathrm{~h})$, the body exhibited a dorsalventral thinning and the wound diameter reduced. The body contraction induced the internalization of the alimentary tract, which disappeared from the wound site and the major blood vessel was not visible. The coelomic fluid and the blood flow ceased (Figure 4B').

Twenty-four hours after the first laser treatment, in the irradiated samples the wound seemed to close and the body wall contracted (Figure 4D), while the non-irradiated samples remained similar to the previous day.

Forty-eight hours after the excision and $24 \mathrm{~h}$ from the second treatment, the irradiated samples wound continued to recover and its color appeared uniform with the rest of the body (Figure 4 F). Conversely, the alimentary tract of the non-irradiated sample remained evaginated, although the body wall was more contracted and both the coelomic fluid and blood were absent (Figure 4E).

Seventy-two hours after the excision and $24 \mathrm{~h}$ from the third treatment, the wound of irradiated samples regained shape and pigmentation in similar form to the rest of the body (Figure 4H), while the non-irradiated wound remained open with the alimentary tract visible (Figure 4G).
Lastly, $144 \mathrm{~h}$ (6 days) after the excision and $96 \mathrm{~h}$ from the third and last treatment, the irradiated posterior excised segments gave an appearance similar to the posterior

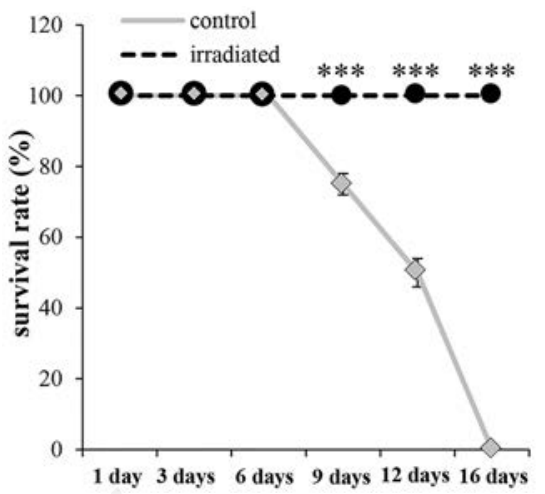

Figure 3. Dendrobaena veneta survival rate expressed as a percentage, in non-irradiated (control) and irradiated (3 irradiation) excised site. No-star symbol $=\mathbf{P}>0.05 ;{ }^{*}=$ $\mathbf{P}<0.05 ;{ }^{* *}=\mathbf{P}<0.01 ;{ }^{* * *}=\mathbf{P}<0.001$.

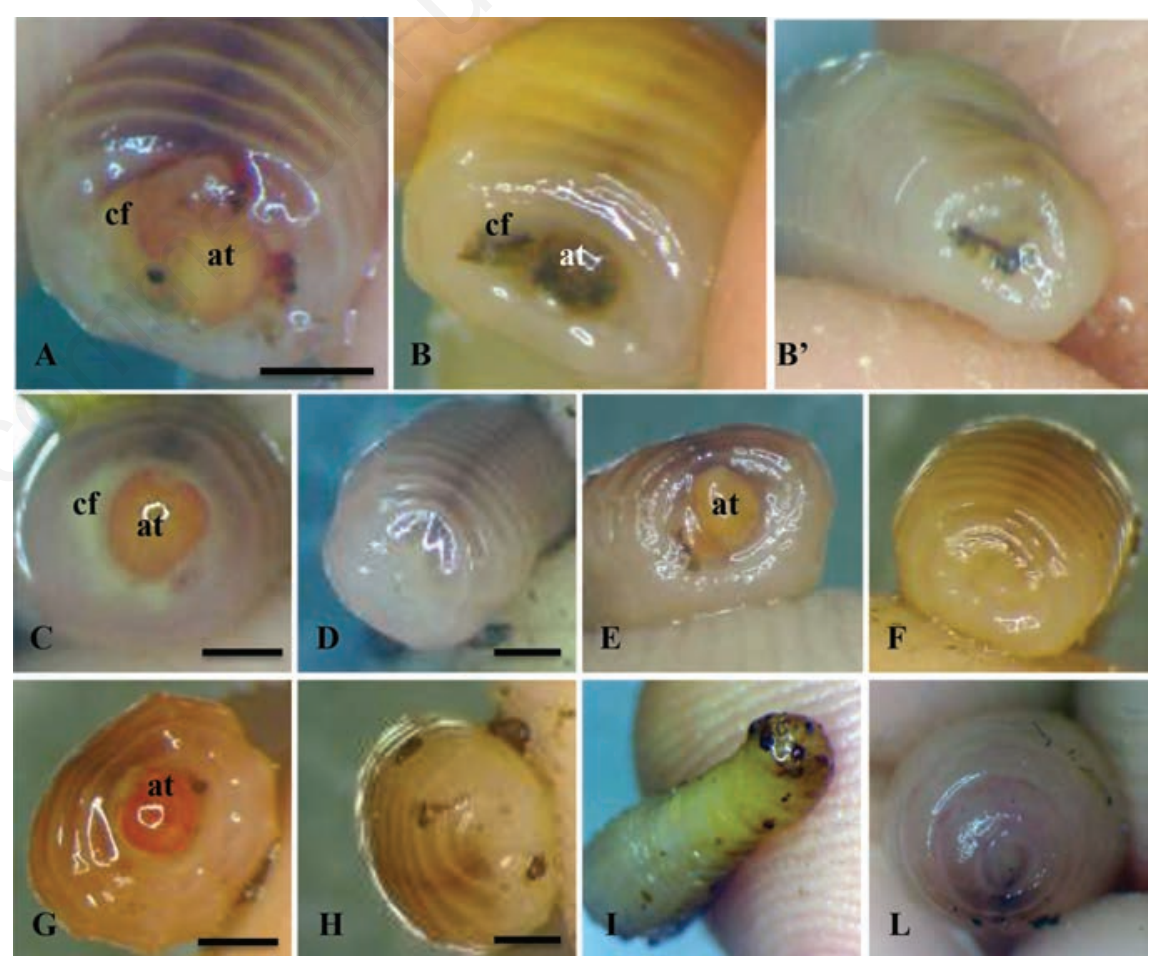

Figure 4. Effect of the laser irradiation on the wound healing of Dendrobaena veneta excised side. Images acquired by Zeiss stereomicroscope. $A=$ earthworm immediately after the excision $(0 \mathrm{~h}) . \mathrm{B}=$ earthworm immediately after the excision $(0 \mathrm{~h})$ and $\mathrm{B}$, the same organism immediately after the first irradiation $(0 \mathrm{~h}) . \mathrm{C}=$ non-irradiated (control) earthworm $24 \mathrm{~h}$ after the excision and $\mathrm{D}$, earthworm $24 \mathrm{~h}$ after the first irradiation. $\mathrm{E}=$ nonirradiated (control) earthworm $48 \mathrm{~h}$ after the excision and $\mathrm{F}$, earthworm $48 \mathrm{~h}$ after the first irradiation and $24 \mathrm{~h}$ after the second irradiation. $\mathrm{G}=$ non-irradiated earthworm $72 \mathrm{~h}$ after the excision and $\mathrm{H}$, earthworm $72 \mathrm{~h}$ after the first irradiation and $48 \mathrm{~h}$ and $24 \mathrm{~h}$ after the second and the third irradiation, respectively. I=non-irradiated earthworm $144 \mathrm{~h}$ after the excision and L, earthworm $144 \mathrm{~h}, 120 \mathrm{~h}$ and $96 \mathrm{~h}$ after the first, second and third irradiation, respectively. at= alimentary tract; $c f=$ coelomic fluid. Bars $=\mathbf{2 . 3} \mathbf{~ m m}$. 
side of a non-excised earthworm (Figure $4 \mathrm{~L}$ ), whereas the non-irradiated samples showed evidence of gangrene (Figure 4I).

\section{Histology - general observations}

Twenty-four hours after the dissection, in the control specimens, the body wall muscles were not contracted, the alimentary tract lumen was in contact with the external environment and the alimentary tract wall was everted, forming a wide protrusion (Figure 5A). The blood vessels close to the wound were enlarged (Figure 6A).

Twenty-four hours after the dissection and the first laser treatment, the body wall muscles were contracted and the alimentary tract wall was non-everted (Figure 5B). The blood vessels close to the wound revealed a reduced lumen compared to the control (Figure 6B).

Forty-eight hours after the dissection, in control specimens, the body wall muscles were partially contracted and formed an easily-visible bulge close to the wound site. The alimentary tract lumen was open to the external environment, and the alimentary tract wall was still everted (Figure 5C), as well as the blood vessels being still enlarged (Figure 6C).

Forty-eight hours after the dissection and the second laser treatments, the edges of the wound appeared near-apposed and the alimentary tract lumen withdrawn into the body cavity (Figure 5D). The blood vessels were still reduced in size (Figure 6D).

Seventy-two hours after the dissection, in control specimens, the alimentary tract was no longer everted and in some cases it appeared withdrawn into the body cavity (Figure 5E).

Seventy-two hours after the dissection and the third laser treatments, the body wall margins had closed and epidermis covered the wound site (Figure 5F).

\section{Histology - body wall muscles}

The body wall muscles in control specimens presented a progressive degeneration, from $24 \mathrm{~h}$ to $72 \mathrm{~h}$ after the dissection (Figure 7 A,C,E); in particular, gaps appeared among the muscle fibers, with a more abundant presence of collagen. The histology of body wall muscles in lasertreated specimens did not show degeneration (Figure 7 B,D,F).

\section{Histology - WGA labeling}

The WGA lectin highlights three different structures in the histological sections of $D$. veneta: the cytoplasm of scattered cells in the peritoneum, which lines the coelom (Figure 8A); cytoplasm of cells among the muscle fibers in the body wall (Figure $8 \mathrm{~B}$ $\mathrm{F})$; granules in the cytoplasm of epidermal cells (Figure 8F).

The scattered WGA-labeled cells in the peritoneum were always present and did not change their aspect and distribution in different specimens. Alternatively, the WGAlabeled cells among the muscle fibers changed their distribution over time and different treatments. In control specimens, they became visible $24 \mathrm{~h}$ after the dissection (Figure 8B) and increased their presence at $48 \mathrm{~h}$ (Figure 8D) and $72 \mathrm{~h}$ (Figure 8F). Also, a continuity between WGA-labeled cells of peritoneum and WGA-labeled cells in the
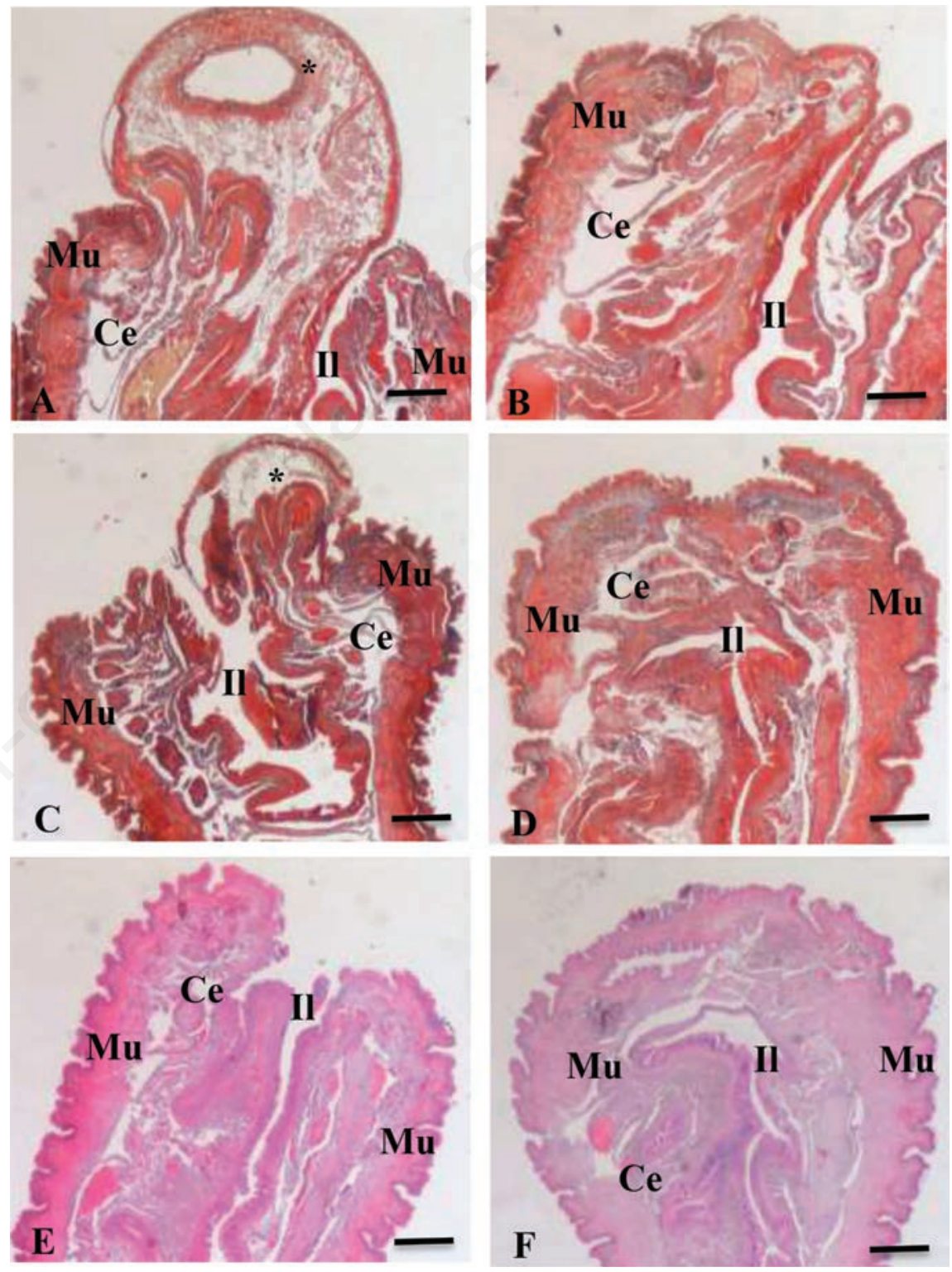

Figure 5. Histological section of 30 posterior excised segments of Dendrobaena veneta. Masson's Trichrome staining (A-D) or Hematoxylin and Eosin staining (E, F). A, C, E= non-irradiated (control) samples, $24 \mathrm{~h}, 48 \mathrm{~h}$ and $72 \mathrm{~h}$ from the excision, respectively. $\mathrm{B}$, $\mathrm{D}, \mathrm{F}=$ irradiated samples, $24 \mathrm{~h}, 48 \mathrm{~h}$ and $72 \mathrm{~h}$ from the excision or, on the other hand after $1,2,3$ irradiations, respectively. ${ }^{*}=$ everted alimentary tract wall. Ce=celom; Il= intestinal lumen; $\mathrm{Mu}=$ muscular tissue. Bars, $300 \mu \mathrm{m}$. 
pared to the uncut $(\mathrm{P}<0.001)$, after the excision in both the irradiated and the non-irradiated posterior segments $(\mathrm{P}>0.05)$ and it remained constant up to $72 \mathrm{~h}$ from the excision (Figure 9). However, at $96 \mathrm{~h}$ the level of telomerase activity was maintained in the irradiated sample, while there was a dramatic decrease in the non-irradiated samples $(\mathrm{P}<0.001)$ (Figure 9).

\section{Evaluation of HSP70 expression}

The HSP70 protein expression increased approximately 10 times in the non-irradiated sample (control), compared to the uncut earthworm, whereas imperceptible, but statistically significant, change was recorded in the irradiated earthworm $(\mathrm{P}<0.001)$ (Figure $10)$. At $48 \mathrm{~h}$ from the excision the non-irradiated earthworm exhibited continued increase in HSP70 expression $(\mathrm{P}<0.001)$ and the irradiated sample retained a protein expression similar to the uncut earthworm $(\mathrm{P}>0.05)$ (Figure 10).

\section{Discussion}

The ability to respond to injury and to repair tissue is a fundamental property of multicellular organisms. In the moments after an injury occurs, various intracellular and intercellular pathways must be activated and coordinated, if tissue integrity and homeostasis are to be restored. ${ }^{19}$ If this response is successful and the injury does not result in the demise of the organism, these processes must be shut down in a precise sequence in the ensuing days as recovery progresses. Notwithstanding differences between varying organisms, the three classic stages of wound repair, inflammation, new tissue formation and remodeling, are observed in almost all eukaryotic organisms. ${ }^{19}$. In our work, the effect of the treatment with $808 \mathrm{~nm}$ diode laser, $64 \mathrm{~J} / \mathrm{cm}^{2}, 1$ $\mathrm{W}(\mathrm{CW})$, on the wound healing of excised posterior segments of $D$. veneta are classified in three steps: immediate effects $(0 \mathrm{~h}$ after irradiation), short-term effects $(24 \mathrm{~h}$, $48 \mathrm{~h}$ and $72 \mathrm{~h}$ after irradiation) and longterm effects ( $72 \mathrm{~h}$ over irradiation).

Immediately after treatment the irradiated $D$. veneta showed evident muscular contraction at the wound site, pointed out by the dorsal-ventral thinning of the body and the internalization of the alimentary tract, which disappeared from the wound site only in irradiated earthworms. Oligochaeta show striate transverse and helical musculature arrangement, ${ }^{27}$ which, like the vertebrate striate musculature, contracts by changes in calcium fluxes and variation of intracellular calcium concentration. ${ }^{28}$ Amaroli et al. ${ }^{14}$ proved the effect of the 808 $\mathrm{nm}$ diode laser $\left(64 \mathrm{~J} / \mathrm{cm}^{2}, 1 \mathrm{~W}\right)$ therapy on
P. primaurelia calcium fluxes and Sharmizaev $^{35}$ showed marked spasmolytic properties of laser irradiation, likely due to calcium signaling in the adjacent muscle's cells. Therefore, our data suggest an effect of the laser on the cellular muscle calcium fluxes, which result in the $D$. veneta striate musculature contraction.

In the moments after irradiation, the PBM decreases the bacteria concentration on the top of excised posterior segments, as revealed by our microbiological analysis. Literature shows that PBM may modify growth of wound bacteria, which could affect wound healing. ${ }^{36}$ In particular, fluences from $4.2 \mathrm{~J} / \mathrm{cm}^{2}$ up to $50 \mathrm{~J} / \mathrm{cm}^{2}$ (CW) and laser light wavelengths in the range of 380-810 $\mathrm{nm}$ can excite endogenous porphyrins and kill the related pigmented-bacteria. ${ }^{36,37}$

We do not know the qualitative effect of our therapy on the earthworm excised posterior segments bacteria populations, however, the quantitative effect is clear and its role in the inflammatory process should not be underestimated. The short-term effects support the observed immediate effects. The histological analysis of samples fixed $24 \mathrm{~h}$ after the first irradiation or non-irradi-
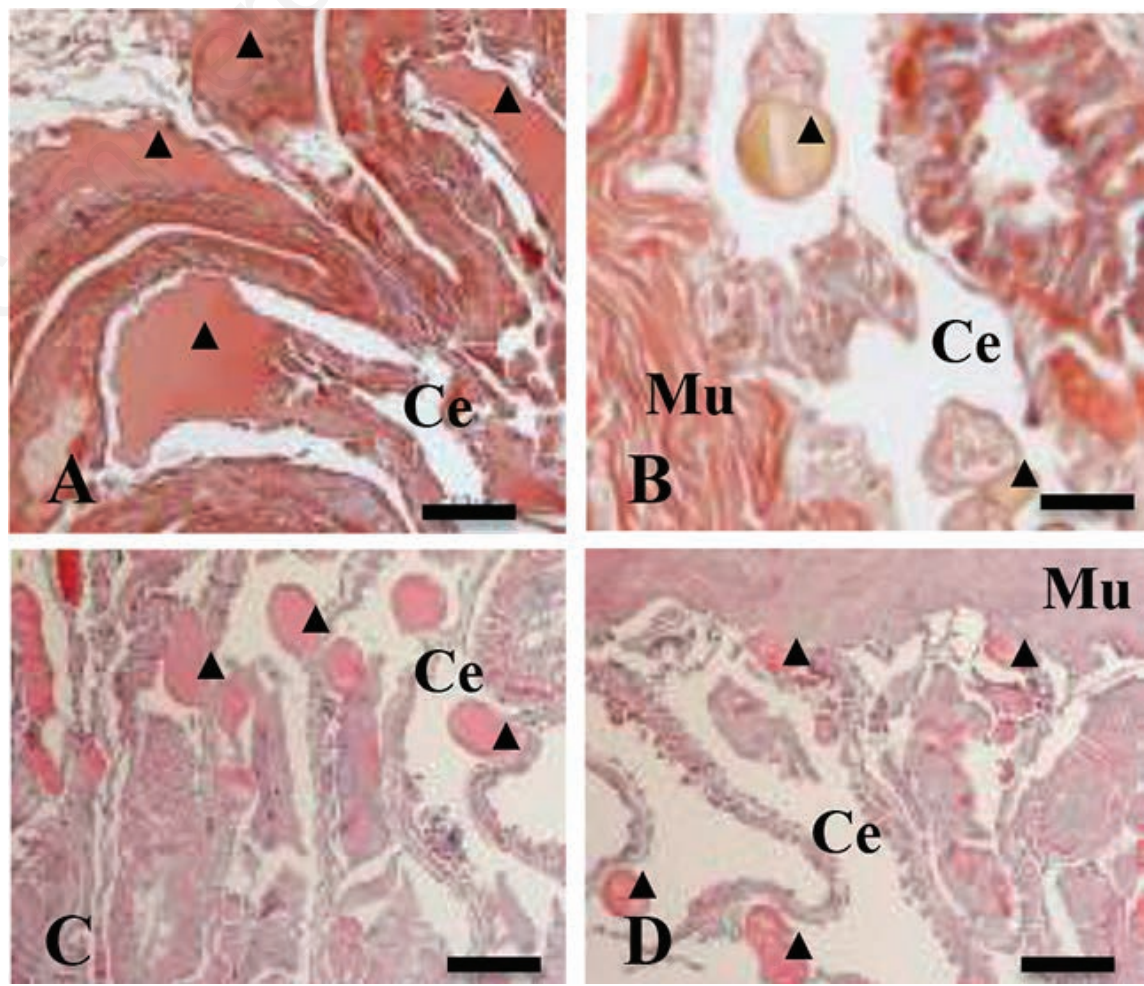

Figure 6. Histological section of Dendrobaena veneta excised side. Masson's Trichrome staining, $24 \mathrm{~h}$ after excision, in non-irradiated (control) (A) and irradiated, 1 irradiation, (B) earthworms. Hematoxylin and Eosin staining, $48 \mathrm{~h}$ after excision, in non-irradiated (control) (C) and irradiated, 2 irradiations, (D) earthworms. A-C-D, bars, $100 \mu \mathrm{m}$. B, bars $20 \mu \mathrm{m}$. $\mathrm{Ce}=$ celom; $\mathrm{Mu}=$ muscular tissue; $\boldsymbol{\Delta}=$ blood vessel lumen. ation, highlights the everted intestine of the controls, which is folded back to expose the inside epithelium. The alimentary tract eversion and the formation of a coelomic plug are the two classical ways to rapidly close the wound, as described in the earthworm Eisenia fetida. ${ }^{25}$ Amaroli et al. ${ }^{24}$ showed that also $D$. veneta is able to produce the coelomic plug and this plug is thinner in the excised earthworm exposed to $808 \mathrm{~nm}$ diode laser, $64 \mathrm{~J} / \mathrm{cm}^{2}, 1 \mathrm{~W}$ therapy, than in the control, as a demonstrable consequence of a decreased inflammatory process.

In our work, in contrast to the control, the irradiated excised tails did not close the wound through alimentary tract eversion, but by a vigorous muscular contraction. The apposition of the irradiated excised tail body wall flaps provides evidence of the consequence of this contraction. In addition, by the Masson's trichrome staining, a new tissue mass is identified. This mass is collagen-free, while the collagen is evident in the flaps of the existing tissue. The differences between irradiated and non-irradiated ) are also evident, for the major fact, their diameter is smaller in the irradiat- 
ed than in the non-irradiated histological sample and the contour edge of blood vessel lumen is more regular in the lasered tails than in the controls. This data concurs with the above-mentioned effect of laser irradiation on the muscular contraction and further supports the possible effect of the laser on calcium fluxes. The endothelial cells of the earthworm are properly considered mioendothelial cells, whose contraction ability increase with the increment of blood vessel lumen. ${ }^{37}$ The earthworm blood vessel contraction relies on the myofilaments, which contract by variations of intracellular calcium concentration..$^{38,39}$ It is not unreasonable therefore to assume, as with the major blood vessels, that our laser irradiation promotes a contraction, with a mechanism similar to that hypothesized for the muscular tissue.

Our histological analysis shows also other evident differences between irradiated and non-irradiated excised tails. Twentyfour hours after the excision, and ever more evident in the following days the muscular fibers progressively became distinct from each other, with the consequent increase in the connective tissue amongst them. This change is clear when observing the longitudinal cross-sections of circle musculature, just below the epidermis, as well as with the longitudinal musculature. Conversely, the irradiated sample had a compact muscular wall, with thin trabecular connective among the fibers. It is known that muscular atrophy is a phenomenon occurring in the organism with muscle tissue as consequence of senescence, inactivity or pathological causes ${ }^{40}$ and in mammalian species a correlation between inflammatory processes and muscle atrophy is documented. ${ }^{41}$ The HSP70 is one of the most conserved proteins of "animal kingdom" and its involvement in the inflammatory process is well documented. ${ }^{31,42}$ In fact, HSP70 is involved in the restoration of cell homeostasis, in the immunoregulation and in the phagocytosis of cellular residue, to promote cell proliferation and wound healing. ${ }^{42}$ Our data show for the first time the expression of HSP70 in D. veneta. In the control samples its expression was time-dependent and highest at $48 \mathrm{~h}$ (+1984\% respect to the non-excised earthworm). The irradiated samples showed increase in HSP70-expression at $24 \mathrm{~h}$ but the increment was very small $(+60 \%$ compared to the non-excised earthworm) and at $48 \mathrm{~h}$, after the third irradiation the HSP70levels were similar to that in the nonexcised earthworm. Therefore, a reduction in the inflammation through PBM without a thermal-shock is evident.

This assertion is supported by our previous results with the $808 \mathrm{~nm}$ diode laser (64 $\left.\mathrm{J} / \mathrm{cm}^{2}, 1 \mathrm{~W}\right)$ therapy, which reduced the $D$. veneta inflammation process, as evident in a decrease of the non-cholinergic acetylcholinesterase production. ${ }^{24}$

The modifications of the muscle of the control samples are also highlighted by the positive labeling of the WGA; absent (24 h) or very scant $(48 \mathrm{~h})$ in the irradiated samples. The interpretation of this staining in both the control-posterior-segment and the irradiated-posterior-segment of excisedearthworms is not clear. However, the progressive temporal increment in the fluorescence in the controls and the near-absence in the irradiated samples, suggests that WGA positive cells promotes alterations correlating to muscular atrophy. Cells normally present in the muscle tissue could become aligned to the WGA positive cells because of the muscle atrophy. However, the labeling of the amoebocytes has not to be excluded. In fact, the WGA strongly labeled the mesenchymal cells lining the coelom. These cells are able to produce amoebocytes, which in the earthworm as in mammalian macrophage, migrate up to the inflamed site, phagocyte debris (like dead cells), foreign particles and microorganisms, promoting wound healing. ${ }^{25}$ The WGA also labeled little structures into the epidermis of the controls, which are too small to be classified as vesicles but also DNA-free, so not catalogued as bacteria. They could be evidence of a virus infection, as reported in Drosophila melanogaster, in which it induces the HSP70 increment. ${ }^{43}$
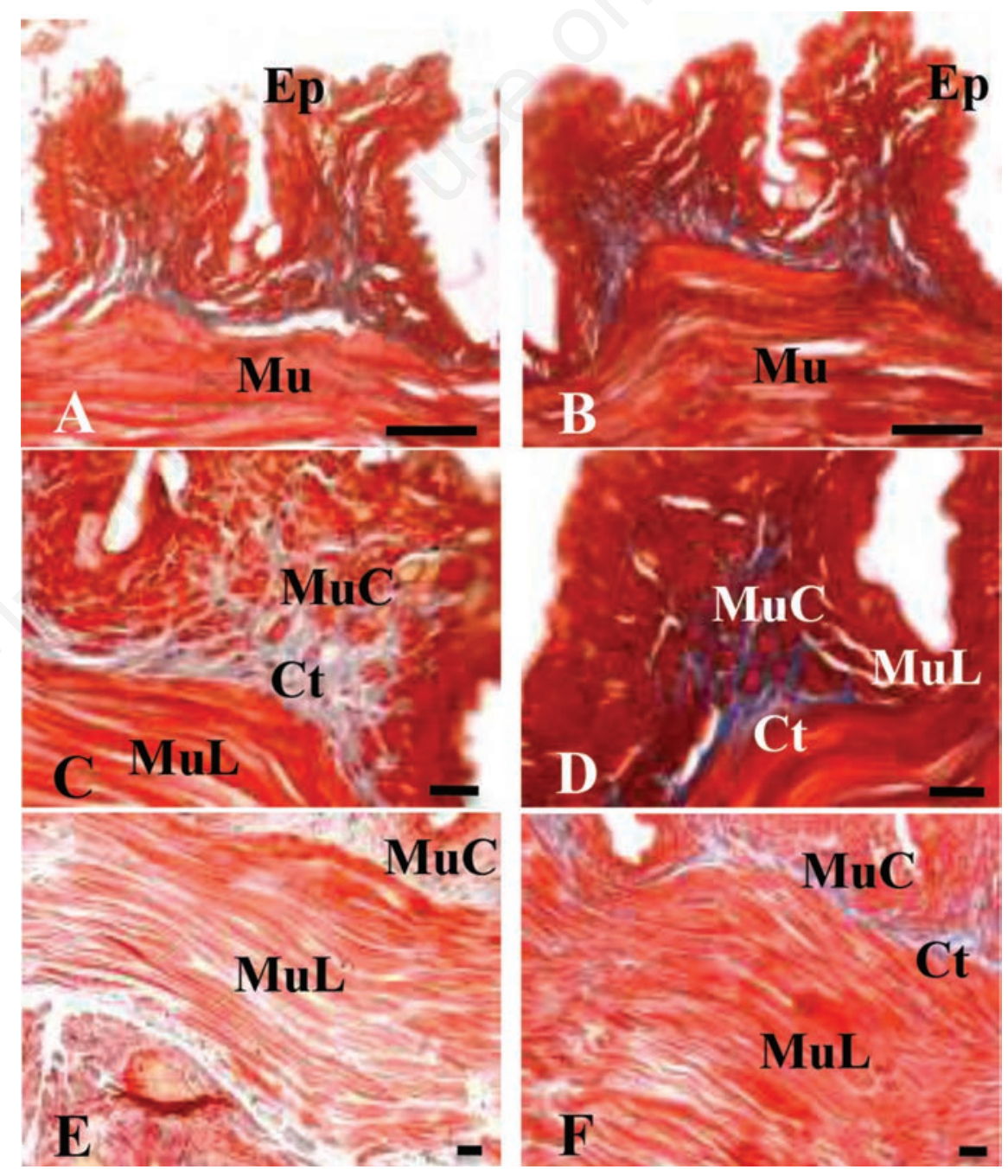

Figure 7. Histological section of Dendrobaena veneta excised side. Masson's Trichrome staining. A,C,E) Non-irradiated (control) samples, 24, 48 and $72 \mathrm{~h}$ from the excision, respectively. $\mathrm{B}, \mathrm{D}, \mathrm{F})$ Irradiated samples, 24,48 and $72 \mathrm{~h}$ from the excision or, on the other hand after 1, 2 and 3 irradiations, respectively. $\mathrm{Ep}$, epidermal tissue; $\mathrm{Mu}$, muscle tissue; $\mathrm{MuC}$, circular muscle tissue; MuL, longitudinal muscle tissue; $\mathrm{Ct}$, connective tissue. Scale bars: $5 \mu \mathrm{m}$. 
However, moving beyond these speculations, it is clear that this was present only in the epidermis of the control, progressively destined to gangrene, but not in the irradiated-epidermis. If the first step in wound healing is the control of the inflammation processes to restore homeostasis, the new tissue formation by new cell proliferation is the second. The histochemical analysis as little as at $24 \mathrm{~h}$ showed new tissue formation in the irradiated excised earthworm, but our evaluation of the telomerase activity pointed out an interesting cell behavior. The excise earthworm had an increment of telomerase activity, compared to the nonexcised earthworm. Up to $72 \mathrm{~h}$, this increment was similar for both irradiated and non-irradiated D. veneta. At $96 \mathrm{~h}$ it decreased drastically in the control, while it remained at high level in the irradiated samples. Actually, the high-level telomerase activity observed at $96 \mathrm{~h}$ in the irradiated organisms cannot be a direct effect of the irradiation (the last irradiation was at $48 \mathrm{~h}$ ). Therefore, if as reported in literature, the telomerase activity is typically correlated to cellular proliferation during the wound healing of mammalian tissue, ${ }^{34}$ we can speculate that the inflammatory processes and the tissue degeneration of non-irradiated excised $D$. veneta deplete the cell energy and its proliferative potential within the fourth day. Conversely, the laser irradiation would allow a more equilibrated employment of cell energy, by the mitigating effect on both inflammation and tissue degeneration and a likely effect on the energetic cellular metabolism, in according to our previous works. ${ }^{9-14}$

A foreseeable consequence therefore emerges when all data is considered; the control specimens become infected, become gangrenous and die, while the irradiated samples complete the wound healing and tissue remodeling and after twelve days they are alive.

Lastly, our results are stressed by the evidence that invertebrate species are as diverse as flies and worms and share a lot of genes and molecular pathways with humans. More than $90 \%$ of the domains that can be identified in human proteins are present in fruit fly and worm proteins, while $61 \%$ of fruit fly proteins and $43 \%$ of worm proteins have high sequence similarities to predicted human proteins. ${ }^{44}$ Furthermore, the gene conservation of earthworms is closer to humans than worms such as the well-known animal model Caenorhabditis elegans. ${ }^{17}$ In fact, the bilaterian metazoan showing bilateral symmetry, are divided into two clades: Deuterostomes and Protostomes. Among Protostomes a further subsequent distinction into two clades is possible: Ecdysozoa and Lophotrochozoa.
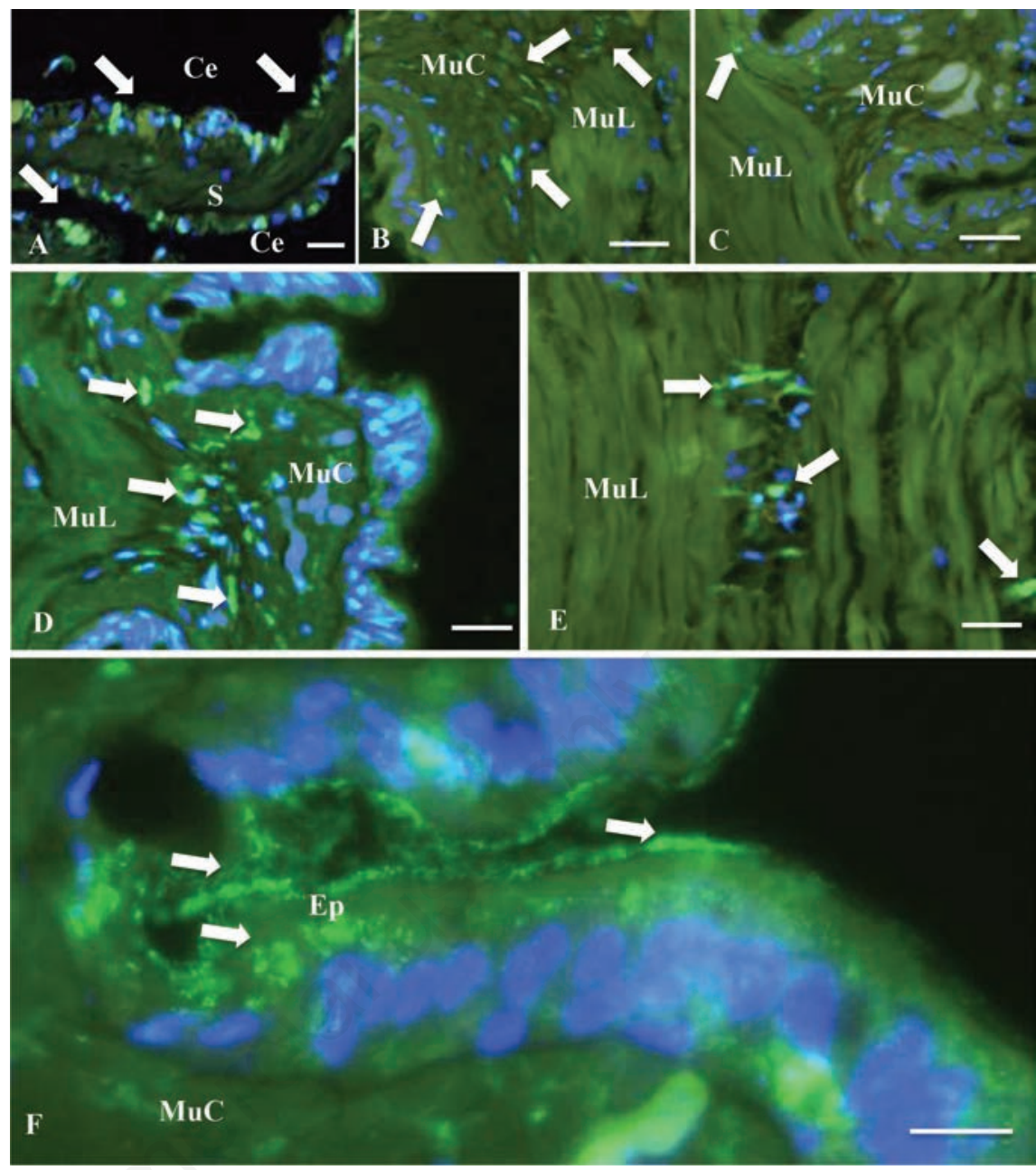

Figure 8. Histological section of Dendrobaena veneta excised side. The Alexa 488-conjugated lectin wheat germ agglutinin (WGA) binds (green fluorescence, white arrows) the $\mathrm{N}$-acetylglucosamine and $\mathrm{N}$-acetylneraminic acids. The DNA is point out by DAPI fluorescence staining (blue fluorescence). A) The WGA is positive in the cytoplasm of scattered cells in the peritoneum of both non-irradiated and irradiated samples. B,D,F) Nonirradiated (control) samples 24,48 and $72 \mathrm{~h}$ after the excision. C,F) Irradiated samples, 24 and $48 \mathrm{~h}$ from the excision or, on the other hand after 1 and 2 irradiations, respectively. Ce,celom; S, septum; Ep, epidermal tissue; MuC, circular muscle tissue; MuL, longitudinal muscle tissue. Scale bars: $50 \mu \mathrm{m}$.

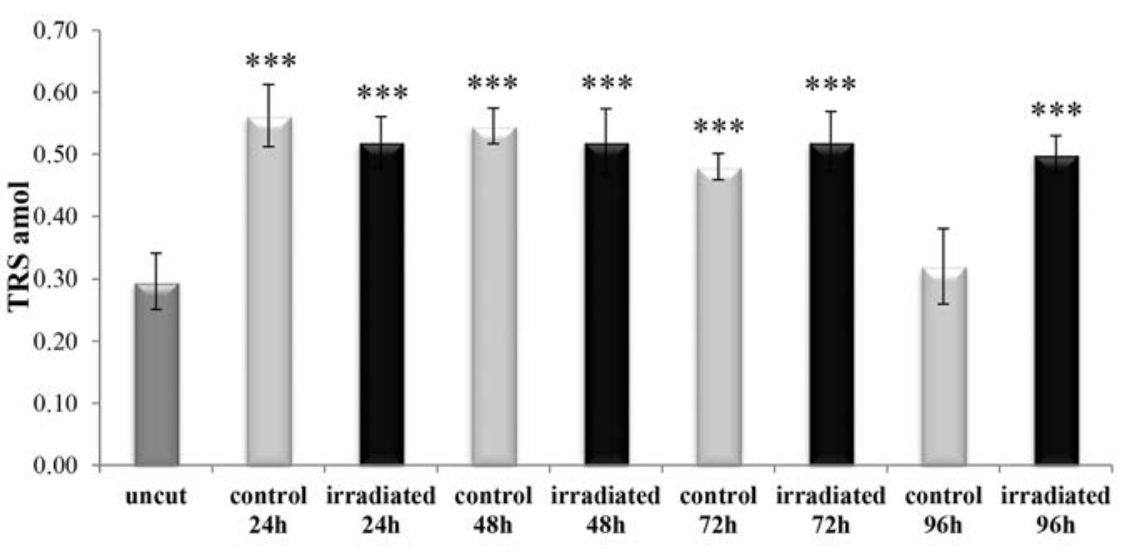

Figure 9. Telomerase activity in uncut, irradiated and non-irradiated (control) Dendrobaena veneta. The star symbol indicates the significant difference respect to the uncut samples. No-star symbol, $\mathrm{P}>0.05 ;{ }^{*} \mathrm{P}<0.05 ;^{* *} \mathrm{P}<0.01 ;{ }^{* * *} \mathrm{P}<0.001$. 


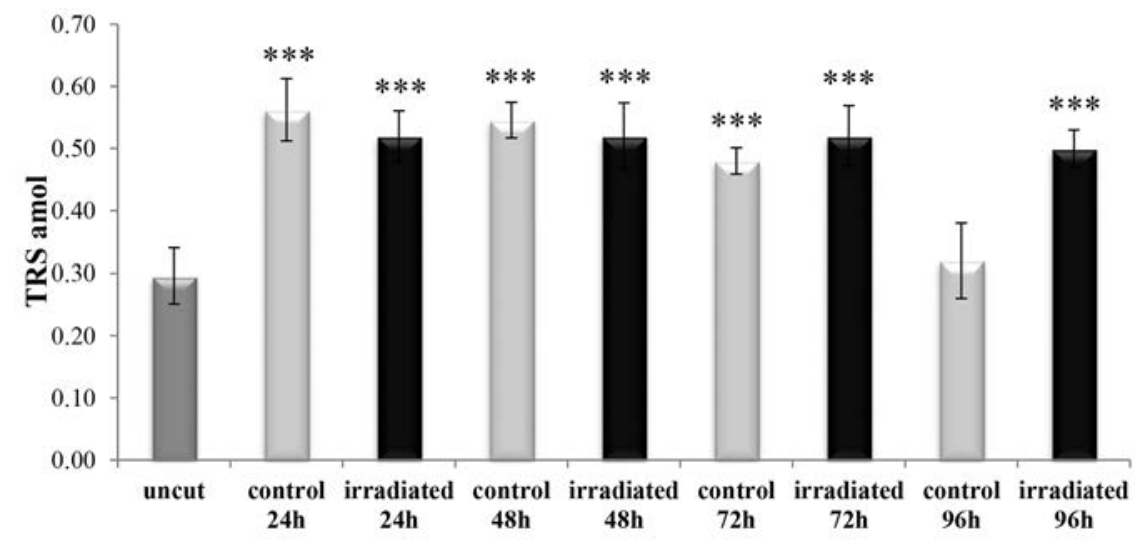

Figure 10. Expression of heat shock protein 70 (HSP70) in uncut, irradiated and nonirradiated (control) Dendrobaena veneta. The star symbol indicates the significant difference respect to the uncut samples. No-star symbol, $P>0.05 ;{ }^{*} P<0.05 ;{ }^{* *} P<0.01$; $* * * \mathbf{P}<\mathbf{0 . 0 0 1}$.

Literature data point out that the vertebrates and Lophotrochozoa have diverged much less from the ancestral genome of the urbilaterian ancestors than has the ecdysozoa genome. ${ }^{44}$ In consequence, vertebrates and Lophotrochozoa are genetically moreeasily compared than vertebrates and Ecdysozoa ${ }^{45}$ Surprisingly, D. melanogaster and $C$. elegans are ecdysozoa, while the Annelida, such as earthworms are Lophotrochozoa.

In conclusion, the $808 \mathrm{~nm}$ diode laser therapy, using a fluence of $64 \mathrm{~J} / \mathrm{cm}^{2}$ at $1 \mathrm{~W}$ (CW) with a flat-top hand-piece, proved to induce positive PBM. This was sustained in the transition from cell to the animal model. Three successive treatments, one every $24 \mathrm{~h}$ are sufficient to promote wound healing, through effects on muscular and blood vessel contraction, decrease in bacteria load, reduction of inflammatory processes and tissue degeneration. $D$. veneta was demonstrated to be a reliable experimental organism that satisfies the request of public opinion in the field of bioethics, the 3 Rs principles $^{16}$ and the National Science Foundation statement ".... All model organisms share a few common traits: They're inexpensive, easy to care for, grow quickly and are relatively simple creatures". ${ }^{46}$

In acknowledgement of their genetic and evolutionary peculiarity, not inferior to those of scientifically accredited models, $D$. veneta allows investigation of the effect of laser therapies by multidisciplinary methods, at various degree of complexity and costs.

\section{References}

1. Mester E, Szende B, Tota JG. Effect of laser on hair growth of mice. Kiserl Orvostud 1967;19:628-61.

2. Parker S. Photobiomodulation: an overview of current concepts and understanding. In: Benedicenti A, Therapy, IV edition. Brescia, Italy; Teamwork media srl; 2016. p. 139-155.

3. Karu T. Primary and secondary mechanisms of action of visible to near-IR radiation on cells. $\mathrm{J}$ Photochem Photobiol B 1999;49:1-17.

4. Hamblin MR, Waynant RW, Anders J, editors. Mechanisms of low level light therapy. International Society for Optics and Photonics. Proc. SPIE 6140; 2006. p 12.

5. Karu TI, Afanas'eva NI. Cytochrome c oxidase as the primary photoacceptor upon laser exposure of cultured cells to visible and near IR-range light. Dokl Akad Nauk 1995;342:693-5.

6. Carati CJ, Anderson SN, Gannon BJ, Piller NB. Treatment of postmastectomy lymphedema with low-level laser therapy: a double blind, placebo-controlled trial. Cancer 2003;98:1114-22.

7. Benedicenti A, Amaroli A, Seting W, Matthew A, Benedicenti S. Case studies on the use of a new flat-top handpiece for biomodulation in dentistry and medicine. J Laser Health Academy 2015;1-6.

8. Selting W. Flat top hand-piece. In: Benedicenti A, Benedicenti S, editors. Atlas of Laser Therapy, IV edition. Brescia, Italy: Teamwork media srl; 2016. p. 225-236.

9. Amaroli A, Ravera S, Parker S, Panfoli I, Benedicenti A, Benedicenti S. An 808-nm diode laser with a flat-top handpiece positively photobiomodulates mitochondria activities. Photomed Benedicenti S, editors. Atlas of Laser
Laser Surg 2016;34:564-71.

10. Amaroli A, Ravera S, Parker S, Panfoli I, Benedicenti A, Benedicenti S. The protozoan Paramecium primaurelia as a non-sentient model to test laser light irradiation: the effects of an $808 \mathrm{~nm}$ infrared laser diode on cellular respiration. Alt Lab Anim - ATLA 2015; 43:155-62.

11. Amaroli A, Parker S, Dorigo G, Benedicenti A, Benedicenti S. Paramecium: a promising non-animal bioassay to study the effect of $808 \mathrm{~nm}$ infrared diode laser photobiomodulation. Photomed Laser Surg 2015;33:35-40.

12. Amaroli A, Ravera S, Parker S, Panfoli I, Benedicenti A, Benedicenti S. Effect of $808 \mathrm{~nm}$ diode laser on swimming behavior, food vacuole formation and endogenous ATP production of Paramecium primaurelia (protozoa). Photochem Photobiol 2015;91:1150-5.

13. Amaroli A, Ravera S, Parker S, Panfoli I, Benedicenti A, Benedicenti S. 808nm laser therapy with a flat-top handpiece photobiomodulates mitochondria activities of Paramecium primaurelia (Protozoa). Lasers Med Sci 2016;31: 741-7.

14. Amaroli A, Benedicenti A, Ferrando S, Gallus L, Selting W, Benedicenti S. Photobiomodulation by infrared diode laser: effects on intracellular calcium concentration and nitric oxide production of Paramecium. Photochem Photobiol 2016;92:854-62.

15. Amaroli A, Gambardella C, Ferrando S, Hanna R, Benedicenti A, Gallus L, el al. The effect of photobiomodulation on the sea urchin Paracentrotus lividus (echinodermata) by using higher-fluence on fertilization, embryogenesis, and larval development: an in vitro study. Photomed Laser Surg 2016; 35:127-35.

16. Russell WMS, Burch RL. The principles of humane experimental technique. London: Methuen; 1959.

17. Cressey D. The year of the worm? Nature 2008. doi:10.1038/news.2008. 1309.

18. Katz PS. Model organisms in the light of evolution. Curr Biol 2016;26:R64950.

19. Gurtner GC, Werner S, Barrandon Y, Longaker MT. Wound repair and regeneration. Nature 2008;453:15.

20. Ansell DM, Holden KA, Hardman MJ. Animal models of wound repair: are they cutting it? Exp Dermatol 2012; 21:581-5.

21. Seok J, Warren HS, Cuenca AG, Mindrinosa MN, Bakerc HV, Xua et al. Genomic responses in mouse models poorly mimic human inflammatory dis- 
eases. Proc Nat Academ Sci USA 2013;110:3507-12.

22. Schork NJ. Personalized medicine: Time for one-person trials. Nature 2015;520:609-11.

23. Lőw P, Molnár K, Kriska G. Atlas of animal anatomy and histology. Springer International Publishing; 2016.

24. Amaroli A, Ferrando S, Hanna R, Gallus L, Benedicenti A, Scarfî S, et al. The photobiomodulation effect of higher-fluence 808 -nm laser therapy with a flat-top handpiece on the wound healing of the earthworm Dendrobaena veneta: a brief report. Lasers Med Sci 2018;33: 221-5.

25. Burke JM. Wound healing in Eiseniafoetida (Oligochaeta). I Histology and 3H-thymidine radioautography of the epidermis. J Exp Zool 1974;188:49-64.

26. Cholewa J, Feeney GP, O'Reilly M, Stürzenbaum SR, Morgan AJ, Płytycz B. Autofluorescence in eleocytes of some earthworm species. Folia Histochem Cytobiol 2006;44:65-71.

27. Lanzavecchia G. Morphofunctional and phylogenetic relations in helical muscles. Boll Zool 1981;48:29-40.

28. Paniagua R, Royuela M, GarcíaAnchuelo RM, Fraile B. Ultrastructure of invertebrate muscle cell types. Histol Histopathol 1996;11:181-201.

29. Dominguez J, Edwards CA. The influence of vermicomposts on plant growth and pest incidence. In: Shakir Hanna SH, Mikha TIWZA, editors. Soil Zoology for Sustainable Development in the 21st Century. Cairo; 2004. p 369-395.

30. Xiao N, Ge F, Edwards CA. The regeneration capacity of an earthworm,
Eisenia fetida, in relation to the site of amputation along the body. Acta Ecol Sinica 2011;21:197-204.

31. Borges TJ, Wieten L, van Herwijnen MJ, Broere F, van der Zee R, Bonorino $\mathrm{C}$, van Eden W. The anti-inflammatory mechanisms of Hsp70. Front Immunol 2012;3:95.

32. Aarskog NK, Vedeler CA. Real-time quantitative polymerase chain reaction. A new method that detects both the peripheral myelin protein 22 duplication in Charcot-Marie-Tooth type 1A disease and the peripheral myelin protein 22 deletion in hereditary neuropathy with liability to pressure palsies. Hum Genet 2000;107:494-8.

33. Vandesompele J, De Preter K, Pattyn F, Poppe B, Van Roy N, De Paepe A, et al. Accurate normalization of real-time quantitative RT-PCR data by geometric averaging of multiple internal control genes. Genome Biol 2002;18;3: research0034.

34. Kim NW, Piatyszek MA, Prowse KR, Kim NW, Piatyszek MA, Prowse KR, et al. Specific association of human telomerase activity with immortal cells and cancer. Science 1994;266:2011-5.

35. Shamirzaev B. Functional properties of laser effects on morphology of liver, gall bladder and bile ducts in cholelithiasis. Med Health Sci J 2012;10:56-61.

36. Nussbaum EL, Lilge L, Mazzulli T. Effects of $810 \mathrm{~nm}$ laser irradiation on in vitro growth of bacteria: comparison of continuous wave and frequency modulated light. Lasers Surg Med 2002;31:343-51.

37. Soukos NS, Som S, Abernethy AD, Ruggiero K, Dunham J, Lee C, et al.
Phototargeting oral black-pigmented bacteria. Antimicrob Agents Chemother 2005;49:1391-6.

38. Hama K. The fine structure of some blood vessels of the earthworm Eisenia foetida. J Biophys Biochem Cytol 1960;7:717-23.

39. Coggeshall RE. A fine structural analysis of the ventral nerve cord and associated sheath of Lumbricus terrestris L. J Comp Neurol 1965;125:393-438.

40. Augustin H, Partridge L. Invertebrate models of age-related muscle degeneration. Biochim Biophys Acta 2009; 1790:1084-94.

41. Ventadour S, Attaix D. Mechanisms of skeletal muscle atrophy. Current Opin Rheumatol 2006;18:631-5.

42. Asea AAA, De Maio A. Heat shock proteins, vol. 1. Heat shock proteins: potent mediators of inflammation and immunity. Springer; Dordrecht; 2007.

43. Merkling SH, Overheul GJ, van Mierlo JT, Arends D, Gilissen C, van Rij RP. The heat shock response restricts virus infections in Drosophila. Sci Rep 2015; $5: 12758$.

44. Rubin GM. The draft sequences: comparing species. Nature 2001;409:820-1.

45. Raible F, Arendt D. Metazoan evolution: some animals are more equal than others. Current Biol 2004;14:R106-8.

46. Arriens J. Earth's weird and wonderful animal models: Simple creatures reveal fundamental biological insights. National Science Foundation; 2016. Available from: https://www.nsf.gov/ mobile/discoveries/disc_summ.jsp?cnt n_id=138386\&org=NSF 